\title{
Peran Guru PKN dalam Pembentukan Karakter Warga Negara
}

\author{
Mariyani \\ Program Studi Pendidikan Pancasila dan Kewarganegaraan \\ Program Pascasarjana Universitas Negeri Yogyakarta \\ Karang Malang, Jl. Colombo No.1, Caturtunggal, Kecamatan Depok, Kabupaten Sleman, \\ Daerah Istimewa Yogyakarta 55281 \\ Mariyani573@gmail.com
}

\begin{abstract}
Character building efforts through education in Indonesia can be said to have not been implemented optimally. It is illustrated by the many behaviors of learners that lead to immoral behavior and contrary to the values of Pancasila. The moral crisis must be addressed immediately by increasing efforts to shape the character of good citizens. Character building through education is charged to every subject at school. One of the subjects charged in shaping the character of good citizens is through Civics subjects. The subject of Civics becomes a very effective approach in achieving the goal of character formation. This paper seeks to describe how the role of Civics teacher as a central figure in shaping the character of learners in accordance with the expected goals. The method used in this paper is a literature review of ideas that strengthen this paper. Teachers become central figures in the learning process so that the role of teachers is very large in shaping the character of learners in accordance with the value of Pancasila. Teachers must change the paradigm that teachers only as teachers become educators. That's because teachers in shaping characters are not through knowledge transfer but are able to bring students in real experience through learning. The role of Civics teachers in forming the character of citizens include 1) the role of teachers as teachers in understanding the values of characters to be developed; 2) the role of teachers as the compilers of character-based learning devices; 3) the role of teachers as implementers of innovative learning and 4) the role of teachers as role models in character building.
\end{abstract}

Keywords: role of teacher, Civics and character education

\begin{abstract}
Abstrak
Upaya pembentukan karakter melalui pendidikan di Indonesia bisa dikatakan belum terlaksana secara optimal. Hal itu tergambar dengan masih banyaknya perilaku peserta didik yang mengarah pada perilaku amoral dan bertentangan dengan nilai-nilai Pancasila. Krisis moral tersebut harus segera diatasi dengan meningkatkan upaya dalam membentuk karakter warga negara yang baik. Pembentukan karakter melalui pendidikan dibebankan pada setiap mata pelajaran di sekolah. Salah satu mata pelajaran yang dibebankan dalam membentuk karakter warga negara yang baik ialah melalui mata pelajaran PKn. Mata pelajaran PKn menjadi pendekatan yang sangat efektif dalam mencapai tujuan pembentukan karakter. Tulisan ini berupaya untuk menguraikan bagaimana peran guru PKn sebagai tokoh sentral dalam membentuk karakter peserta didik sesuai dengan tujuan yang diharapkan. Metode yang digunakan dalam penulisan ini ialah kajian pustaka berupa gagasan yang memperkuat tulisan ini. Guru menjadi tokoh sentral dalam proses pembelajaran sehingga peran guru sangatlah besar dalam membentuk karakter peserta didik yang sesuai dengan nilai Pancasila. Guru harus
\end{abstract}


merubah paradigma bahwa guru hanya sebagai pengajar menjadi sebagai pendidik. Hal itu dikarenakan guru dalam membentuk karakter tidak melalui transfer pengetahuan saja tetapi mampu membawa siswa dalam pengalaman nyata melalui pembelajaran. Adapun peran guru PKn dalam pembentukan karakter warga negara meliputi 1) peran guru sebagai pengajar dalam memahami nilai-nilai karakter yang akan dikembangkan; 2) peran guru sebagai penyusun perangkat pembelajaran berbasis karakter; 3) peran guru sebagai pelaksana pembelajaran yang inovatif dan 4) peran guru sebagai teladan dalam pembentukan karakter.

\section{Kata Kunci: peran guru, PKn dan pendidikan karakter}

\section{PENDAHULUAN}

Pemerintah pada tahun 2017 melalui Peraturan Presiden No 87 Tahun 2017 mengeluarkan program untuk meningkatkan kualitas pendidikan. Program tersebut dikenal dengan program Penguatan Pendidikan Karakter (PPK). Program PPK bertujuan untuk memperkuat tujuan pendidikan nasional dalam membentuk karakter peserta didik yang sesuai dengan nilai-nilai Pancasila. Upaya penguatan tersebut dilakukan tidak hanya melalui sekolah tetapi juga berbasis masyarakat. Setiap komponen wajib memberikan sumbangsih yang besar dalam upaya penguatan pendidikan karakter.

Penguatan pendidikan karakter dilakukan karena masih banyaknya fenomenafenomena yang tidak menunjukkan karakter warga negara yang baik. Warga negara yang baik yang dimaksud ialah warga negara yang mampu mengaktualisasikan nilai-nilai Pancasila dengan tepat sehingga terwujudnya smart citizen dan good citizen. Hal itu diperkuat oleh bahwa ditengarai ada tujuh krisis moral di tengah-tengah masyarakat Indonesia, yaitu: 1) krisis kejujuran; 2) krisis tanggung jawab; 3) tidak berpikir jauh ke depan; 4) krisis disiplin; 5) krisis kebersamaan; 6) krisis keadilan; dan 7) krisis kepedulian ${ }^{1}$. Sebenarnya, masalahmasalah tersebut bukan hanya dialami oleh Indonesia, tetapi juga bangsa-bangsa lain di dunia. Uraian di atas jelas bahwa karakter yang sesuai dengan nilai Pancasila masih harus

${ }^{1}$ Ginanjar, Ali, Pembentukan habit menerapkan nilai-nilai religius, sosial dan akademik (Yogyakarta: Universitas Negeri Yogyakarta). Hlm: 8-9 dibumikan karena masih merosotnya karakter warga negara. Oleh karena itu pendidikan merupakan tombak utama dan paling efektif dalam membentuk karakter warga negara. Karakter warga negara yang diharapkan sejalan dengan tujuan pendidikan nasional yaitu warga negara yang demokratis dan tanggung jawab. Seseorang yang berkarakter baik ialah seseorang yang mempu membuat keputusan dan mampu menerima konsekuensi atas perilakunya ${ }^{2}$.

Pembentukan karakter melalui pendidikan dibebankan pada setiap mata pelajaran. Akan tetapi mata pelajaran yang diberikan tanggung jawab lebih besar dalam pembentukan karakter ialah mata pelajaran PKn dan PAI. Salah satu tujuan dari mata pelajaran PKn ialah pembentukan karakter warga negara. Hakikatnya Pendidikan Kewarganegaraan di Indonesia secara programatik ditujukan pada tujuan akhir ialah membentuk warga negara yang baik (good citizen atau good citizenship) sesuai dengan jiwa dan nilai Pancasila ${ }^{3}$. Guru menjadi sentral utama dalam membentuk karakter peserta didik di sekolah. Hal itu dikarenakan guru berperan dalam upaya menanamkan dan mengembangkan nilai-nilai baik yang bermanfaat bagi peserta didik dalam membentuk karakter yang diharapkan. Guru bertanggungjawab dalam membentuk perilaku peserta didik yang sesuai dengan nilai-nilai Pancasila.

${ }^{2}$ Suyanto, Urgensi pendidikan karakter (Tersedia: [Online] http://www.mandikdasmen.depdiknas.go.id/ web/pages/urgensi.html.

${ }^{3}$ Hakim, Suparlan, Pendidikan Kewarganegaraan dalam konteks Indonesia (Malang: Madani, 2014). 
Guru PKn haruslah merubah paradigma bahwa guru hanya sebagai pengajar menjadi guru sebagai pendidik. Hal itu dilakukan melalui tindakan yang dikemas dalam pembelajaran yang efektif. Guru PKn yang menjadi ujung tombak menanamkan nilai-nilai karakter kadang kala belum mampu memahami makna peran guru sebagai pendidik. Guru merupakan pendidik profesional dengan tugas utamanya mendidik, mengajar, membimbing, mengarahkan, melatih dan mengevaluasi peserta didik setiap jenjang pendidikan ${ }^{4}$. Guru menjadi salah satu komponen dalam proses belajar mengajar yang berperan dalam pembentukan sumber daya manusia yang seutuhnya. Oleh karena itu peran guru dalam pembelajaran haruslah dilaksanakan secara aktif dan memposisikan dirinya sebagai tenaga profesional sesuai dengan tuntutan masyarakat yang makin berkembang. Secara khusus guru bertanggungjawab dalam membawa peserta didik pada taraf kedewasaan tertentu. Dalam rangka ini guru tidak hanya sebagai pengajar yang hanya mentransfer ilmu pengetahuan tetapi juga sebagai pendidik yang melakukan transfer nilai-nilai dan sekaligus menjadi pembimbing yang memberikan pengarahan dan menuntun siswa dalam belajar ${ }^{5}$.

Secara umum ada beberapa peran guru yang memiliki relevansi langsung dengan proses pembelajaran yang meliputi: 1) guru sebagai pendidik, yang menjadi tokoh, panutan, dan identifikasi bagi para peserta didik, dan lingkungannya. Oleh karena itu, guru harus memiliki standar kualitas pribadi tertentu, yang mencakup tanggungjawab, wibawa, mandiri, dan disiplin; 2) guru sebagai pengajar yang bertugas membantu peserta didik yang sedang berkembang untuk mempelajari sesuatu yang belum diketahuinya, membentuk kompetensi dan memahami materi standar yang dipelajari; 3) guru sebagai pembimbing yang berarti guru dapat diibaratkan sebagai pembimbing

\footnotetext{
${ }^{4}$ Sholeh, Membangun profesionalitas guru: Analisis kronologi atas lahirnya UU guru dan dosen. (Jakarta; Elsas, 2006) Hal: 157.

${ }^{5}$ Sardiman, Interaksi dan motivasi belajar mengajar (Jakarta: PT Raja Grafindo, 2008). Hal: 125
}

perjalanan (Guide) berdasarkan pengetahuan dan pengalamannya bertanggungjawab atas kelancaran perjalanan itu; 4) guru sebagai pelatih. Proses pendidikandan pembelajaranmemerlukan latihan keterampilan, baik intelektual maupun motorik, sehingga menuntut guru untuk bertindak sebagai pelatih; 5) guru sebagai penasehat; 6) Guru sebagai model dan teladan. Guru merupakan model atau teladan bagi para peserta didik dan semua orang yang menganggap dia sebagai guru; 7) Guru sebagai pendorong kreatifitas. Kreatifitas merupakan hal yang sangat penting dalam pembelajaran dan guru dituntut untuk mendemonstrasikan dan menunjukkan proses kreatifitas tersebut; 8) guru sebagai aktor harus melakukan apa yang ada dalam naskah yang telah disusun dengan mempertimbangkan pesan yang akan disampaikan kepada peserta didik; 9) guru sebagai emansipator. Dengan kecerdikannya, guru mampu memahami potensi peserta didik, menghormati setiap insan, dan menyadari bahwa kebanyakan insan merupakan "budak" stagnasi kebudayaan dan 10) Guru sebagai evaluator. Evaluasi atau penilaian merupakan aspek pembelajaran yang paling kompleks, karena melibatkan banyak latar belakang dan hubungan, serta variabel lain yang mempunyai arti apabila berhubungan dengan konteks yang hampir tidak mungkin dapat dipisahkan dengan setiap segi penilaian ${ }^{6}$. Oleh karena itu penting mengetahui peran guru $\mathrm{PKn}$ dalam pembentukan karakter warga negara.

\section{METODE PENELITIAN}

Penulisan artikel ini menggunakan metode penelitian tinjauan pustaka (library research) yang bersumber baik dari jurnal maupun buku yang terkait mengenai peran guru PKn dalam pembentukan karakter warga negara. Beberapa referensi seperti artikel dari Cholisin, Mudri, Walid, Kristi, Wardani, Ellis dan Haas, akan menjadi sumber gagasan utama dalam penulisan artikel ini.

\footnotetext{
${ }^{6}$ Mudri, Walid, Kompetensi dan peranan guru dalam pembelajaran (dalam jurnal Falasifa 2010). Hal: 116-121
} 


\section{HASIL DAN PEMBAHASAN}

\section{Peran Guru PKn dalam Pembentukan} Karakter Warga Negara

Pencapaian tujuan pendidikan yang berkualitas akan lebih mudah dengan mempersiapkan guru yang profesional. Guru yang profesional tentu akan lebih mengefektifkan untuk mencapai tujuan pembentukan dan pengembangan karakter peserta didik. Akan tetapi banyaknya kasus-kasus yang menunjukkan kegagalan pendidikan dalam membentuk karakter seseorang dikarenakan ketersediaan guru profesional belum tercapai dengan baik. Merubah paradigma bahwa guru tidak hanya sebagai pengajar yang bertugas mentransferkan ilmu pengetahuan saja tetapi juga menjadi guru sebagai pendidik bukanlah mudah oleh karena itu perlu dikembangkan peran guru dalam mencapai tujuan pembentukan dan pengembangan karakter peserta didik. Penulis berupaya menguraiakan peran guru PKn dalam membentuk dan mengembangkan karakter peserta didik. Secara khusus peran guru PKn dalam membentuk karakter dikarenakan) bahwa secara khusus untuk mencapai pendidikan karakter dapat dilakukan melalui kajian moral yang tidak bisa dipisahkan dengan Pendidikan Kewarganegaraan? ${ }^{7}$.

\section{Peran Guru Sebagai Pengajar dalam Memahami Nilai-Nilai Karakter yang akan Dikembangkan Pada Peserta Didik}

Salah satu peran guru ialah sebagai pengajar yang berarti guru memiliki kompetensi yang memadai mengenai pengetahuan yang akan disampaikan di kelas. Pentingnya pemahaman guru mengenai konsep dan indikator karakter yang hendak dibentuk dan dikembangkan dikarenakan guru merupakan tokoh utama dalam membentuk dan mengembangkan nilai karakter sehingga pemahaman guru haruslah selalu ditingkatkan ${ }^{8}$. Hal ini memperkuat

${ }^{7}$ Arthur, D, \& Lewis, M,. Professional values and practice achieving the standards for QTS. (London and New York. Routledge Falmer, 2005).

${ }^{8}$ Cholisin, Peran guru PKn dalam pendidikan karakter. Makalah Kuliah Umum Jurusan PPKn FKIP bahwa hakikatnya guru PKn haruslah memiliki pemahaman konsep yang luas dan baik terhadap nilai-nilai karakter yang akan dikembangkan. Pemahaman tersebut dapat di peroleh guru melalui banyaknya keikutsertaan dalam pelatihan, workshop dan kegiatan MGMP. Pemahaman tentang konsep nilai karakter yang matang akan mempermudah guru untuk menuangkannya dalam perangkat pembelajaran yang akan di buat.

Adanya MGMP akan sangat membantu guru dalam memahami konsep nilai-nilai karakter yang akan dikembangkan. Tujuan MGMP pada hakikatnya membantu guru untuk 1) meningkatkan kemampuan guru dibidang keilmuannya masing-masing dalam merancang perangkat pembelajaran, pelaksanaan hingga evaluasi; 2) mendiskusikan permasalahan yang dihadapi sehingga mampu bertukar pikiran untuk meningkatan kualitas pembelajaran; 3) membantu guru memperoleh informasi untuk mengembangkan diri melalui penguasaan iptek serta 4) meningkatkan sikap kepercayaan diri sehingga guru selalu mengembangkan pembelajaran yang inovatif ${ }^{9}$. Berdasarkan hal tersebut jelas bahwa melalui adanya MGMP sangat efektif untuk membantu guru bertukar pikiran dan memahami konsep nilai-nilai karakter yang akan dikembangankan dalam pembelajaran.

\section{Peran Guru Sebagai Penyusun Perangkat Pembelajaran Berbasis Karakter}

Peran guru juga salah satunya ialah kemampuan mengembangkan nilai-nilai karakter di dalam perangkat pembelajaran yang telah terlebih dahulu dibuat. Adanya perangkat pembelajaran tentu mempermudah guru untuk

UAD Yogyakarta (dapat diakses melalui http://staffnew. uny.ac.id/upload/131474282/penelitian/PERAN+GUR U+PKn+DALAM+PENDIDIKAN+KARAKTER_ 2 . pdf, 2011). Hal: 5

${ }^{9}$ Saondi, Ondi dan Aris Suherman, Etika profesi keguruan. (Bandung: PT Refika Aditama, 2010).Hal: 81 dan Zulacchah, Peran MGMP dalam meningkatkan profesionalisme guru sejarah (Studi kasus pada MGMP sejarah Kabupaten Kendal, 2006). Hal: 15. 
mencapai tujuan yang dikehendaki. Adapun hal-hal yang harus dimuat dalam perangkat pembelajaran ialah tujuan pembelajaran/ kompetensi, materi pembelajaran, pelaksanaan pembelajaran dan evaluasi. Implementasi pembelajaran tersebut dimulai dari pembuatan silabus dan RPP yang dimulai dari 1) pengkajian kompetensi inti dan kompetensi dasar; 2) mengidentifikasi tujuan dan capaian indikator yang akan di capai; 3) pengembangan materi pokok untuk dapat menentukan nilai-nilai karakter yang akan dikembangkan; 3) melibatkan siswa dalam pembelajaran aktif sehingga nilainilai karakter tersebut mampu di amati dengan baik; dan 4) melakukan penilaian sikap ${ }^{10}$.

Penyusunan perangkat pembelajaran dalam tulisan ini dapat dilakukan melalui beberapa tahap mulai 1) penanaman nilainilai karakter dalam penyusunan rencana pembelajaran mulai dari tujuan, metode, media, dan evaluasi; 2) penanaman nilai-nilai karakter dalam pelaksanaan pembelajaran mulai dari pengembangan bahan ajar yang menekankan penanaman pada nilai-nilai karakter, penyediaan kasus-kasus yang memerlukan pemecahan masalah, pemilihan metode yang memfokuskan pada pelaksanaan pembelajaran yang partisipasi aktif sehingga pelaksanaan pembelajaran dilakukan secara optimal; 3) penilaian yang bertumpu pada penilaian sikap (afektif) yang memuat nilai-nilai karakter seperti sikap menghargai perbedaan. Penyusunan perangkat pembelajaran yang tepat tentu akan mempermudah guru untuk mencapai tujuan pembentukan karakter peserta didik yang diharapkan.

\section{Peran Guru Sebagai Pelaksana Pembelajaran yang Inovatif}

Peran guru dalam hal ini sangatlah kompleks karena guru berperan dan terlibat langsung dalam pembelajaran. Sehingga peran guru sebagai pelaksana pembelajaran

\footnotetext{
${ }^{10}$ Afandi, Muhammad, Perencanaan pembelajaran Pendidikan dasar. ( dalam Jurnal Ilmiah Kependidikan. 1 (2), , 2009). Hal: 147-161
}

akan sangat berkembang dalam melaksanakan perannya sebagai pengelola kelas, mediator, demonstrator, fasilitator, pendorong kreatifitas bahkan sampai evaluator. Peran guru dalam melaksanakan pembelajaran yang paling efektif dalam upaya membentuk dan mengembangan karakter warga negara ialah pemilihan model pembelajaran PKn inovatif yang dapat diterapkan di dalam pembelajaran di kelas. Kata kunci pembelajaran PKn ialah partisipasi aktif. Untuk mengembangkan partisipasi siswa guru dapat menggunakan model pembelajaran seperti: community service (pelayanan masyarakat), model konflik, model pembuatan keputusan (decision making), model riset dan project citizen yang memperkenalkan siswa dengan lapangan kebijakan publik melalui pembelajaran PKn sebagai pendidikan demokrasi membuat siswa belajar peran dan tanggung jawab mereka sebagai warga negara ${ }^{11}$. Sejalan pendapat di atas Citizenship Foundation menyebutkan beberapa model dan strategi dalam pembelajaran PKn untuk membentuk warga negara meliputi 1) Learning climate, 2) topical and controversial issues, 3) active learning, 4) group discussions and debates, 5) developing discussion skills, 6) project work, dan 7) written activities ${ }^{12}$

Model pembelajaran di atas hanyalah sebagian yang dapat dijadikan alternatif oleh guru dalam mengembangkan atau membentuk karakter yang dapat diintegrasikan dalam pembelajaran. Guru mampu mengembangkan nilai-nilai karakter melalui model pembelajaran yang lain sesuai dengan kebutuhan peserta didik dan kesesuaian tujuan pembelajaran yang

${ }^{11}$ Ellis, Arthur K, Teaching and Learning Elementary Social Studies. (Boston: Ally and Bacon, 1998). Hal: 225 dan Haas, Nancy, "Using We the People....Programs in Social Studies Teacher Education,"dalam John J. Patrick dan Robert S. Leming, Principles and Practices of Dernocracy in the Education of Social Studies Teachers, Bloomington. (IN: ERIC Clearinghouse for Social Studies/Social Science Education, ERIC Clearinghouse for International Civic Education, and Civitas, 2001). Pp: 167-185

${ }^{12}$ Citizenship Foundation. CPD Handbook Section 3. Citizenship in secondary schools, (London: Citizenship Foundation, 2006). 
diharapkan. Pembelajaran yang inovatif tersebut akan mampu mengembangkan nilai-nilai karakter yang akan diharapkan. Pada kurikulum 2013 pembelajaran di kelas menekankan pada pembentukan karakter peserta didik melalui keterlibatan peserta didik (student center) guru hanyalah sebagaifasilitator sehingga dengan keterlibatan langsung dalam pembelajaran peserta didik mampu terbentuk dengan mudah nilai-nilai karakter yang hendak dibentuk dan dikembangkan.

Pada kurikulum 2013 ada beberapa tahap dalam pembelajaran yang dilakukan yaitu pendahuluan, pelaksanaan dan penutup. Kegiatan inti menggunanakan metode yang dipilih sesuai kebutuhan dan karakteristik peserta didik. Pelaksanaan pembelajaran mulai dari kegiatan mengamati, menanya, eksplorasi, mengasosiasi dan mengkomunikasikan. Model pembelajaran yang akan di fokuskan dalam tulisan ini ialah metode klarifikasi nilai (VCT) yang menekankan pada kemampuan untuk untuk memilih, memilah, memahami dan mengeksplorasi dari beragam konsekuensi nilainilai moral sehingga mampu diterapkan dalam kehidupan seseorang. Hal ini berkaitan dengan salah satu upaya untuk tidak hanya transfer ilmu pengetahuan tetapi juga mampu mengambil sikap yang dianggap baik dalam menyelesaikan suatu persoalan ${ }^{13}$.

Pada Tabel 1 penulis menguraikan langkah-langkah pembelajaran VCT yang berbasis karakter secara umum.

\section{Peran Guru Sebagai Teladan dalam Pembentukan dan Pengembangan Karakter Warga Negara}

Peran guru dalam konsep pendidikan karakter telah dikenal melalui konsep Ki Hajar Dewantara dengan semboyan "ing ngarsa sung tuladha, ing madya mangun karsa, tut wuri Handayani". Semboyan ini jelas

${ }^{13}$ Hall, B. Value Clarification as Learning Process. (New York: Paulist Press, 1973). Hal: 11. Dan Sanjaya Strategi pembelajaran berorientasi standar proses pendidikan. ( Jakarta: Kencana Preanda Media Group, 2018). Hal: 283 menggambarkan bahwa peran guru sebagai panutan/teladan bagi peserta didik dalam setiap kegiatan yang dilakukan. Konsep keteladanan dari Ki Hajar Dewantara juga di perkuat oleh hasil Kristi Wardani berjudul "Peran Guru dalam Pendidikan Karakter Menurut Konsep Pendidikan Ki Hadjar Dewantara". Penelitian tersebut semakin mempertegas bahwa konsep pendidikan karakter dan moral telah digagas oleh konsep Ki Hajar Dewantara yang mengintegrasikan tri pusat pendidikan yang di mulai dari lingkungan keluarga, lingkungan sekolah, dan lingkungan sosial. Kristi Wardani mengemukakan bahwa peran lingkungan sekolah dalah hal ini guru menjadi semakin kompleks dan memberikan pengaruh yang besar dalam terbentuknya karakter peserta $\operatorname{didik}^{14}$.

Peran guru tidak sekedar sebagai pengajar semata yang mentransferkan ilmu pengetahuan tetapi juga merupakan pendidik yang berusaha membentuk dan mengembangkan karakter untuk peserta didik. Guru haruslah menjadi teladan/panutan/model bagi peserta didik dalam upaya mewujudkan perilaku yang berkarakter yang meliputi olah pikir, olah hati, dan olah rasa.

Konsep pendidikan melalui gagasan Ki Hadjar Dewantara dikenal dengan cara mendidik yang diterapkan di Taman Siswa. Konsep-konsep tersebut meliputi 1) sistem among yang berarti mengemong anak dengan memberikan kebebasan kepada anak tetapi guru akan selalu mengawasi tindakan yang dilakukan dengan baik; 2) Tut Wuri Handayani yang berarti pemimpin mengikuti dari belakang, memberi kemerdekaan bergerak yang dipimpinnya, tetapi handayani, mempengaruhi dengan daya kekuatan, kalau perlu dengan paksaan dan kekerasan apabila kebebasan yang diberikan itu di pergunakan untuk hal-hal yang tidak baik; 3) Tringa yang meliputi ngarti, ngrasa, dan nglakoni. Konsep ini berupaya untuk

\footnotetext{
${ }^{14}$ Kristi, Wardani, Peran guru dalam pendidikan karakter menurut konsep pendidikan Ki Hadjar Dewantara. (Proceeding of the $4^{\text {th }}$ International Conference on Teacher Education: Join Conference UPI \& UPSI Bandung, 2010). Hal: 230-239.
} 
Tabel 1. Langkah Pembelajaran VCT, Peran Guru dan Nilai yang dikembangkan

\begin{tabular}{|c|c|c|}
\hline Langkah Pembelajaran & Peran guru & Nilai yang dikembangkan \\
\hline \multicolumn{3}{|l|}{ Pendahuluan } \\
\hline $\begin{array}{l}\text { Siswa bersama guru memulai pembelajaran dengan } \\
\text { berdoa }\end{array}$ & Guru sebagai pembimbing & Nilai religius \\
\hline $\begin{array}{l}\text { Siswa bersama guru mempersiapkan kebutuhan untuk } \\
\text { melaksanakan pembelajaran }\end{array}$ & Guru sebagai fasilitator & $\begin{array}{l}\text { Disiplin dan tanggung } \\
\text { jawab }\end{array}$ \\
\hline $\begin{array}{l}\text { Siswa dan guru memahami tujuan pembelajaran apa } \\
\text { yang akan dicapai }\end{array}$ & Guru sebagai pengajar & Nilai kerjasama \\
\hline \multicolumn{3}{|l|}{ Pelaksanaan } \\
\hline $\begin{array}{l}\text { Siswa memperoleh stimulus oleh guru baik berupa } \\
\text { gambar, maupun keadaan yang sesuai dengan tujuan } \\
\text { yang akan dicapai }\end{array}$ & $\begin{array}{l}\text { Guru sebagai fasilitator dan } \\
\text { mediator }\end{array}$ & Rasa ingin tahu \\
\hline $\begin{array}{l}\text { Siswa akan diamati oleh guru mengenai respon yang } \\
\text { akan diberikan setelah mendapatkan stimulus }\end{array}$ & Guru sebagai evaluator & Tanggung Jawab \\
\hline $\begin{array}{l}\text { Siswa dipandu oleh guru melaksanakan dialog } \\
\text { terpimpin baik secara individu, kelompok ataupun } \\
\text { klasikal }\end{array}$ & $\begin{array}{l}\text { Guru sebagai fasilitator dan } \\
\text { pendidik }\end{array}$ & $\begin{array}{c}\text { Kerjasama, tanggung jawab, } \\
\text { berani mengemukakan } \\
\text { pendapat, disiplin, } \\
\text { menghargai pendapa orang, } \\
\text { mandiri }\end{array}$ \\
\hline $\begin{array}{l}\text { Siswa mampu menentukan argumen dan klarifikasi } \\
\text { terhadap pendiriannya }\end{array}$ & $\begin{array}{l}\text { Guru sebagai pembimbing } \\
\text { dan pendidik }\end{array}$ & $\begin{array}{l}\text { Mandiri, tanggung jawab, } \\
\text { percaya diri, }\end{array}$ \\
\hline $\begin{array}{l}\text { Setelah menentukan maka siswa mampu membuktikan } \\
\text { argumentasi }\end{array}$ & Guru sebagai fasilitator & $\begin{array}{l}\text { Mandiri dan tanggung } \\
\text { jawab }\end{array}$ \\
\hline \multicolumn{3}{|l|}{ Penutup } \\
\hline $\begin{array}{l}\text { Siswa bersama guru memyimpulkan hasil } \\
\text { pembelajaran melalui VCT }\end{array}$ & $\begin{array}{l}\text { Guru sebagai fasilitator dan } \\
\text { pendidik }\end{array}$ & Kerjasama \\
\hline Siswa memperoleh tugas tambahan sebagai pengayaan & Guru sebagai pengajar & $\begin{array}{l}\text { Mandiri dan tanggung } \\
\text { jawab }\end{array}$ \\
\hline
\end{tabular}

mengingatkan bahwa nilai-nilai yang baik, citacita hidup dan pemahaman seseorang haruslah dapat dimengerti sehingga mampu diolah pikir dan diimplementasikan dalam bentuk nyata melalui perbuatan. Tahu dan mengerti saja tidak cukup jika belum diaktualisasikan dalam kehidupan nyata.

Pentingnnya keteladanan guru juga dikemukakan bahwa untuk menjadi teladan/ panutan seorang guru haruslah mampu menunjukkan perilaku yang positif sehingga peserta didik dapat mencontoh dan menghormati guru tersebut ${ }^{15}$. Apapun yang dikatakan dan

${ }^{15}$ Crosby, J. The good teacher is more than a lecturer: the twelve roles of the teacher. (AMEE Education Guide No 20. Scottish Council for Postgraduate Medical \& Dental Education. Medical Teacher 22(4), 2000) pp. 334-347 dilakukan oleh guru baik di kelas maupun di luar kelas maka akan memberikan pengaruh besar terhadap keefektifan pembentukan dan pengembangan peserta didik. Oleh karena itu peran guru terutama guru PKn tidak hanya mentransfer ilmu tetapi juga mampu menjadi teladan mulai dari kepribadian, pembiasaan, dan contoh yang ditampilkan oleh guru dalam berpenampilan, bertutur kata, berperilaku yang baik, disiplin, hubungan dengan Tuhan, hubungan dengan diri sendiri, kehidupan sosial, kehidupan keluarga, moral, sikap, kecerdasan intelektual, tampilan fisik, dan keteladanan beribadah. Keteladanan guru sangat besar pengaruhnya terhadap pertumbuhan dan perkembangan pribadi para peserta didik. 


\section{KESIMPULAN}

Pembentukan karakter peserta didik sangat tergantung pada keberhasilan peran guru PKn dalam upaya menanamkan dan mengembangkan nilai-nilai karakter yang akan dicapai. Karakter-karakter yang dikembangkan haruslah sesuai dengan karakter-karakter utama yang menjadi tujuan mata pelajaran PKn. Adapun peran yang dapat dilakukan guru dalam tulisan ini ialah pertama, peran guru sebagai pengajar dalam memahami nilai-nilai karakter yang akan di kembangkan pada peserta didik.

Salah satu peran guru ialah sebagai pengajar yang berarti guru memiliki kompetensi yang memadai mengenai pengetahuan yang akan disampaikan di kelas.

Hal ini memperkuat bahwa hakikatnya guru PKn haruslah memiliki pemahaman konsep yang luas dan baik terhadap nilai-nilai karakter yang akan dikembangkan. Pemahaman tersebut dapat di peroleh guru melalui banyaknya keikutsertaan dalam pelatihan, workshop dan kegiatan MGMP.

Peran guru sebagai penyusun perangkat pembelajaran berbasis karakter.

Kedua, peran guru juga salah satunya ialah kemampuan mengembangkan nilainilai karakter yang dikembangkan di dalam perangkat pembelajaran yang telah terlebih dahulu dibuat. Adanya perangkat pembelajaran tentu mempermudah guru untuk mencapai tujuan yang dikehendaki. Penyusunan perangkat pembelajaran dalam tulisan ini dapat dilakukan melalui beberapa tahap mulai 1) Penanaman nilai-nilai karakter dalam penyusunan rencana pembelajaran mulai dari tujuan, metode, media, dan evaluasi; 2) Penanaman nilai-nilai karakter dalam pelaksanaan pembelajaran; 3) penilaian yang bertumpu pada penilaian sikap (afektif) yang memuat nilai-nilai karakter seperti sikap menghargai perbedaan.

Ketiga, peran guru sebagai pelaksana pembelajaran yang inovatif. Peran guru dalam hal ini sangatlah kompleks karena guru berperan dan terlibat langsung dalam pembelajaran. Sehingga peran guru sebagai pelaksana pembelajaran akan sangat berkembang dalam melaksanakan perannya sebagai pengelola kelas, mediator, demonstrator, fasilitator, pendorong kreatifitas bahkan sampai evaluator. Peran guru dalam melaksanakan pembelajaran yang paling efektif ialah pemilihan model pembelajaran PKn inovatif yang dapat diterapkan di dalam pembelajaran di kelas.

Dan keempat, peran guru terutama guru PKn tidak hanya mentransfer ilmu tetapi juga mampu menjadi teladan mulai dari kepribadian, pembiasaan, dan contoh yang ditampilkan oleh guru dalam berpenampilan, bertutur kata dan berperilaku yang baik.

\section{DAFTAR PUSTAKA}

Afandi, Muhammad. (2009). Perencanaan pembelajaran Pendidikan dasar. Jurnal Ilmiah Kependidikan. 1 (2) hal: 147-161

Arthur, D, \& Lewis, M,. (2005). Professional values and practice achieving the standards for QTS. London and New York. Routledge Falmer.

Cholisin. (2011). Peran guru PKn dalam pendidikan karakter. Makalah Kuliah Umum Jurusan PPKn FKIP UAD Yogyakarta. 5 Februari 2011 di akses 5 November pukul 22.15 melalui http:// staffnew.uny.ac.id/upload/131474282/ penelitian/PERAN+GURU+PKn+DALA M+PENDIDIKAN+KARAKTER_2.pdf

Citizenship Foundation. (2006) CPD Handbook Section 3. Citizenship in secondary schools,London: Citizenship Foundation.

Crosby, J. (2000). The good teacher is more than a lecturer: the twelve roles of the teacher. AMEE Education Guide No 20. Scottish Council for Postgraduate Medical \& Dental Education. Medical Teacher 22(4): pp. 334-347

Ellis, Arthur K. (1998). Teaching and Learning Elementary Social Studies. Boston: Ally and Bacon

Ginanjar, Ary. (2008). Pembentukan habit menerapkan nilai-nilai religius, sosial dan akademik. Yogyakarta: Universitas Negeri Yogyakarta. 
Haas, Nancy. (2001). "Using We the People.... Programs in Social Studies Teacher Education,"dalam John J. Patrick dan Robert S. Leming, Principles and Practices of Dernocracy in the Education of Social StudiesTeachers, Bloomington, IN: ERIC Clearinghouse for Social Studies/Social Science Education, ERIC Clearinghouse for International Civic Education, and Civitas, Pp: 167-185

Hall, B. (1973). Value Clarification as Learning Process. New York: Paulist Press.

Hakim, S. (2014). Pendidikan kewarganegaraan dalam konteks Indonesia. Malang: Madani

Kristi, Wardani. (2010). Peran guru dalam pendidikan karakter menurut konsep pendidikan Ki Hadjar Dewantara. Proceeding of the $4^{\text {th }}$ International Conference on Teacher Education: Join Conference UPI \& UPSI Bandung, hal: 230-239.

Mudri, Walid (2010). Kompetensi dan peranan guru dalam pembelajaran. Jurnal Falasifa, 1 (1), hal: 11-124
Peraturan Presiden No 87 Tahun 2017 Tentang Penguatan Pendidikan Karakter

Sanjaya, Wina. (2008). Strategi pembelajaran berorientasi standar proses pendidikan. Jakarta: Kencana Preanda Media Group. Saondi, Ondi dan Aris Suherman. (2010). Etika profesi keguruan. Bandung: PT Refika Aditama.

Sardiman, A. M. (2008). Interaksi dan motivasi belajar mengajar. Jakarta: PT Raja Grafindo Persada

Sholeh,A. N.(2006). Membangun profesionalitas guru: analisis kronologis atas lahirnya UU guru dan dosen. Jakarta: eLSAS.

Suyanto. (2011). "Urgensi Pendidikan Karakter". Tersedia: [Online] http://www. mandikdasmen.depdiknas.go.id/web/ pages/urgensi.html. (4 Februari 2018)

Zulacchah. (2006). Peran MGMP dalam meningkatkan profesionalisme guru sejarah (Studi kasus pada MGMP sejarah Kabupaten Kendal). Skripsi. Semarang: Fakultas Ilmu Sosial UNNES 